日臨外会誌 $49(3), 497-501,1988$

症例

僧帽弁穿孔が原因と考えられる一次孔心房中隔欠損再開通の 1 例

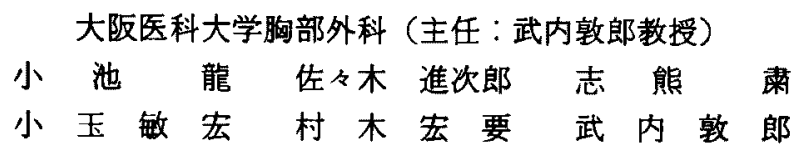

症例は40藏男性で, 9 年前に心房中隔一次孔ハッチ閉鎖術を5けている. 3 年前から. 動悸・労作時呼吸困難を認め, 精査を行ったところ心房レへルでの左一右短絡, Sellers III 度の僧帽弁閉鎖不全症, 高度の三尖羊閉鎖不全症が判明し昭和61年 3 月再手術を行。 た. 前回, 自己心膜を用いてハッチを当てた部分に $15 \times 15 \mathrm{~mm}$ の欠損がみられ，三尖弁 陯は33mmに払大していた。僧帽弁前尖に直径 $7 \mathrm{~mm}$ の穿孔を認めた。僧帽弁葉は脆弱で あるが，㾁贅など感染を示唆する所見は無かった。両弁ともにDuromedics 人工并を用 いて并置換し，心房中隔再開通部をゴフテックスでハッ千閉鎖した。绎過は良好で，患 者は手術 1 年 3 カ月後の現在, 完全に社会復帰している.

心房中隔欠損閉鎖術後の遗残短絡は，0.8 22.7\%の頻度でみられる合併症であるが， 両房室弁閉鎖不全症を伴い再手術を要する症例は少ないと考えられ，文献的考察を加兄 報告した。

事引用語：ASD 遭残短絡，ASD 再手術，僧帽弁穿孔

心房中隔欠損 (ASD) 閉鎖街後の遺矪短絡は 0.8 22.7\%の頻度 ${ }^{1) \sim 10}$ で認められる合併症である が，両房室弁閉鎖不全症を伴い再手術を必要とする症 例は少ないと考えられる.

最近，一次孔心房中隔欠損 (ASDI) に対するバッチ 閉鎖手術か. 99 年後に, ASDI の再開通, 僧棺弁閉鎖不 全症 (MR) 及び三尖弁閉鎖不全症 (TR) を哭症し再 手街を必要とした症例を経検したので若干の文献的考 察を加之報告する。

\section{症例}

症例：40歳, 男性, 事務員

主訴：動楼, 労作時呼吸困難

家族歴：特記すべきことなし

現病歴：小児期から心雑音を指摘されていたが自覚 应状なく放置していた３1歳時，運動時の息切れを認 かるようになり，精查を受けASDI と診断され手術を 受けた。 その㻮の所見は僧帽弁クレフトは軽微のため 放置, ASDI の大きさは $38 \times 24 \mathrm{~mm} て ゙ ，$ 自己心膜を用い てハッチ閉鎖を施行されている。

その後心雑音は消失し，運動耐容能も正常となった。

昭和 62 年 6 月 12 日受付 62 年12月 22 日採用
手術 8 年後の定期検診で心雑音の再発, 胸部写真上心 陰影の执大を指摘され，程なく労作時呼吸困難、動悸 が出現したため再入院した。

入院時理学所見 : $169 \mathrm{~cm}, 66 \mathrm{~kg}$, 栄養良, 血正 $112 /$ $70 \mathrm{mmHg}$ ，脈拍 $72 /$ 分, 不整, 貧血黄迋なし, 腹水なし, 肝 2 横指触知頸部静脈怒張あり，下肢に軽度浮腫あり， 胸部正中に手術創あり，胸骨右縁第 4 肋間から心尖部 にかけて4/VI度の沉収縮期雑音を㯖取。肺野は呼吸音 清.

血液生化学所見：特に異常を認めず.

動脈血培養：陰性.

心電図所見：心房細動，左軸偏位，右脚プロックを 認める。

胸部写真（図 1)：心胸郭比 (CTR) 66\%，肺血管陰 影の軽度増強を認める。

心腈カテーテル検査：心房レベルでの左一右短絡を 認め肺・体血流比は2.74であった，各部位での圧は以 下の如くであった。

右心房匤平均 $10 \mathrm{mmHg}$ ，右心室圧 $33 / 0 \mathrm{mmHg}$ 右室 桩張終期压 $9 \mathrm{mmHg}$ ，肺動脈圧 $35 / 12 \mathrm{mmHg}$ 平均 19 $\mathrm{mmHg}$, 肺動脈揳入王平均 $10 \mathrm{mmHg}$ ，大動脈王 $88 / 56$ $\mathrm{mmHg}$, 平均 $68 \mathrm{mmHg}$, 左室圧 $96 / 0 \mathrm{mmHg}$, 左室終期 


\section{Before initial operation Before re-operation After re-operation}

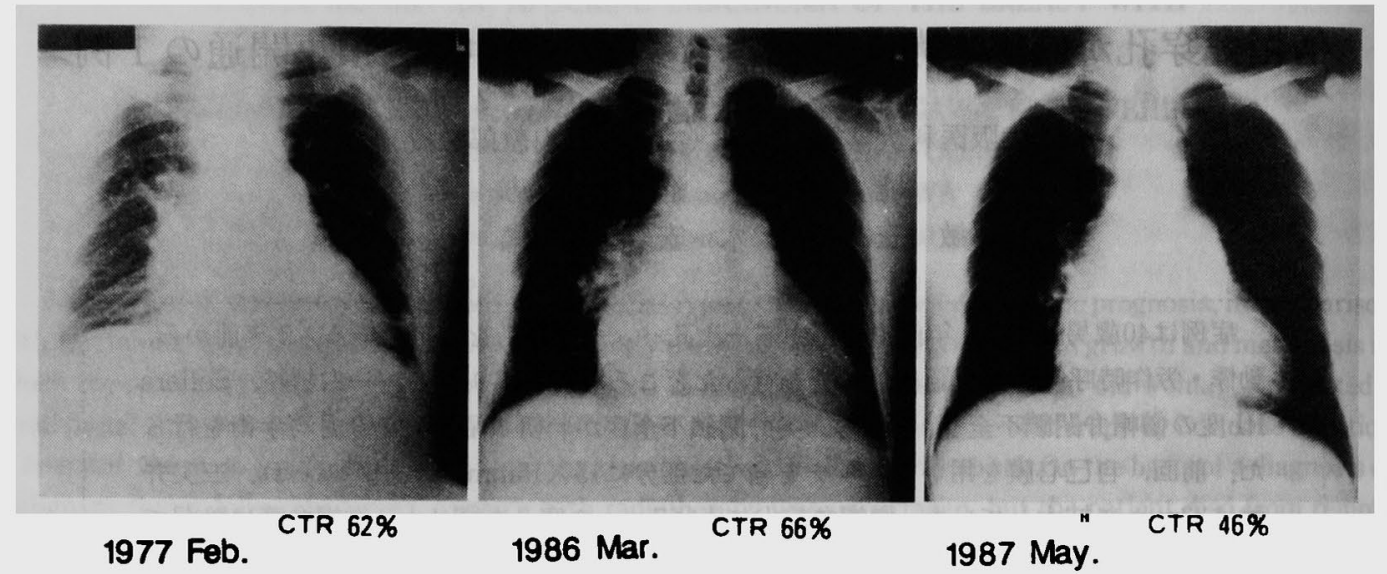

図 1 胸部写兵の推移

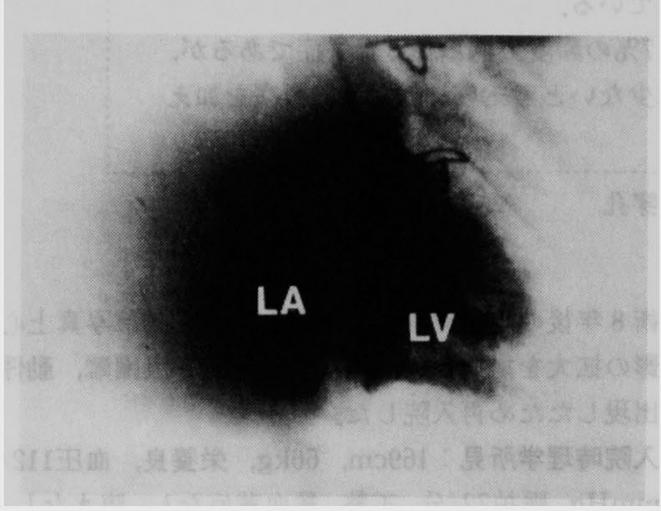

図2 左室造影：LV：左室, LA : 左房. Sellers $\mathrm{III}^{\circ}$ の僧帽弁逆流を認める。

\section{圧 $15 \mathrm{mmHg}$.}

左宔造影（図 2)：Sellers III 度の僧帽弁逆流を認め る.

右室造影（図 3 ）：高度の三尖弁逆流を認める.

以上から遗残 ASD, MR およびTRの診断で初回手 術から 9 年 1 月後の昭和 61 年 3 月に再手術を行った.

再手術所見およU手技（図 4)：中等度低体温体外循 環下に大動脈遮断, cardioplegia で心停止を得, 右心 房を切開すると前回パッチ閉鎖を行った部分に $15 \times 15$ $\mathrm{mm}$ の久損を認めた。心房中隔を欠損を含んで上下に 切開し僧帽弁を観察すると，前尖クレフトは前回手術 時と同様に軽度であった。しかし僧帽弁前尖のほぼ中 央に, 初回手術時に認めなかった直径 $7 \mathrm{~mm}$, 辺縁不整 の穿孔をあらたに認めた(図 5 )。腱索の断裂，疮贅な

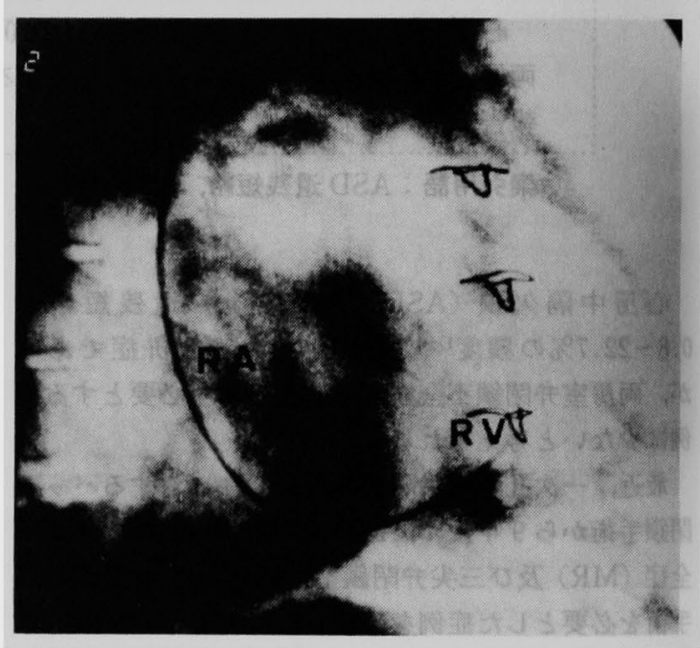

図 3 右室造影：RV：右室, RA：右房. 高度の三尖 并逆流を認める.

どの感染性心内膜炎を示唆する所見は無かった，弁葉 は穿孔部を中心として全体に菲薄かつ脆弱で修復不可 能であったのでDuromedics 人工弁29M 用いて僧 帽弁置換術 (MVR)を行った。 三尖弁はクレフトは認 めなかったが，并輪は 4 横指に拡大し，中隔尖の退行 萎縮が著明であったので Duromedics 人工并31Mを 用いて三尖弁置換術（TVR）を行った。すなわち両房 室弁を切除した後, ASDI再開通部を expanded polytetrafluoroethylene (ジテテックス)を用いてバッ 千閉鎖しつつ，僧帽弁用人下弁を再建された人下中隔 と升輪部に䋖着した。人工隔により欠損部を閉鎖し 


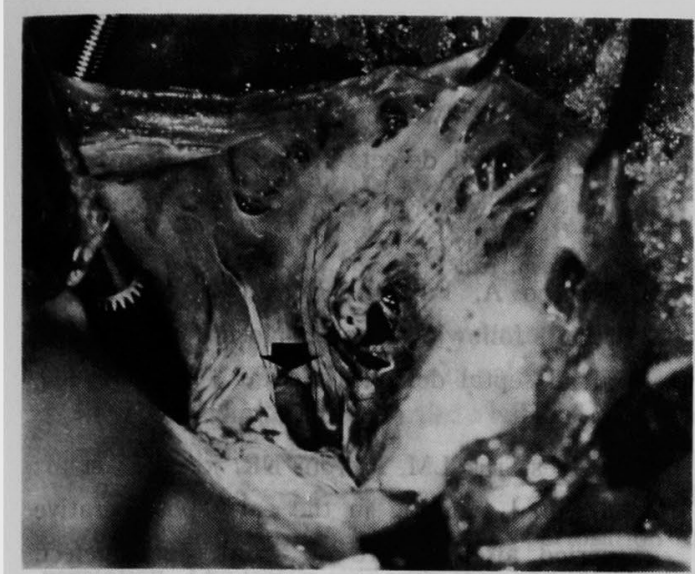

\section{DEFECT}

图4再手術所見：右房を切開したところいで示す部 位に ASD 再開通を認め, 三尖弁輪は 4 横指に払大 し中隔尖の退行萎縮を認める.

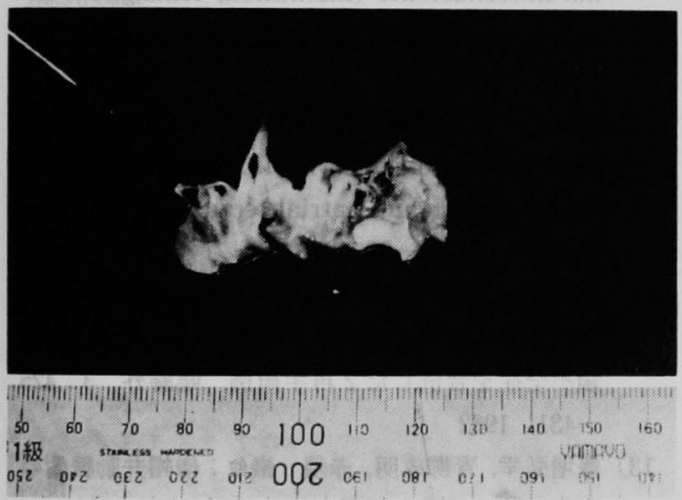

図 5 摘出僧帽弁：前尖中央部に直径 $7 \mathrm{~mm}$, 辺縁不整 の穿孔 (ソンデ挿入部)を認める.

た後，三尖弁用人工弁を人工中隔に䋖着，同様に置換 した. 両人工弁とも supra-annularにうえられており， 左室及び右室流出路を障害することはなく，また人工 中隔に䋖着することで人工弁が傾斜しないように配虑 した.

術後経過は良好で手術15月後の現在，患者は社会復 㷌している。

\section{考察}

近年，心臓外科の手術手技，体外循環法，心筇保護 法の進歩にともなって, ASDの手術は極めて安全なも のとなっている、しかし本症例のような成人例におい、 ては, 術後遠隔期の肺高血圧症の残存, 不整脈の発生
表 1 ASD 道残短絡の発生㥧度

\begin{tabular}{l|c|c|c}
\hline Sellers & 1966 & $6 / 91$ & $(6.6 \%)$ \\
\hline Arnfred & 1966 & $8 / 77$ & $(10.4 \%)$ \\
\hline Cohn & 1967 & $11 / 148$ & $(7.4 \%)$ \\
\hline Hayashi & 1969 & $2 / 155$ & $(1.3 \%)$ \\
\hline Dave & 1973 & $2 / 31$ & $(6.5 \%)$ \\
\hline Young & 1973 & $2 / 12$ & $(16.7 \%)$ \\
\hline Breyer & 1979 & $1 / 43$ & $(2.3 \%)$ \\
\hline Mizuno & 1980 & $4 / 467$ & $(0.8 \%)$ \\
\hline Valdes Cruz & 1982 & $10 / 44$ & $(22.7 \%)$ \\
\hline Körfer & 1984 & $17 / 297$ & $(5.7 \%)$ \\
\hline
\end{tabular}

とならんで ASD 再開通を含む遺残短絡の発生が問題 点としてあげられる。

ASD 手術後の遺残短絡 (再開通を含む) の発生頻度 を表 1 に示す。これらの報告は, Valdes-Cruz ら以外 は全て術後再カテーテル検査にて追跡し得た数字であ ク. $0.8 \%$ 16.7\%の頻度であるが年代の古いものに発 生頻度の高い傾向が認められる.Valdes-Cruz ら9は 手術早期に心エコー検査を行い44例中の10例(22.4\%) といら高率に遺残短絡を認め, 5ち 3 例を large shunt のために再手術を行ったと報告しており心ェコーで定 期的に経過観察することを推奨している。

本症例では，手術 8 年後まで無症状であったことか ら，それまでは良好な血行動態が維持されていたもの と考えられ，多くの報告にあるように ASDの遺残が 徐々に進展したとは考え難い，手術 9 年後急速な他覚 的所見おょび自覚症状の増悪をみていることから $\mathrm{ASD}$ ハッチ部の再開通が突然生じたものと考えられ る. 再手術所見で初回手術時に認めなかった僧帽弁前 尖の穿孔を新たに確認しえたことから推察すると、こ の弁穿孔が引き金となり僧帽弁輪が徐々に払大して高 度 MRに進展し左房が扗大し，その張力か心心房中隔に 加わるようになって ASD が再開通したものと考えら れる。さらには再開通した ASDを通じての左一右大 量シャントによる容量負荷により，三尖弁輪が払大し 高度 TR を発生したものと考えられた。

Ben-Zvi ら ${ }^{11}$ は ASD 術後遠隔期に MR が発生進行 した 4 例を報告しており，猪股ら ${ }^{12)}$ は術前から MR が 存在しそれを放置して ASD 閉鎖手術を行ったところ 遠隔期に MR の増覀と ASD の再開通を認め再手術を 行った 2 例を報告しており，術前から MR が存在する 場合には心房中隔に緊張が加わらないよう欠損孔は值 
接閉鎖するよりパッチ閉鎖すべきとの示唆を与えてい る。

しかし本症例の如く，初回手術時に intactであった 僧帽弁の穿孔をみとめた ASD 再開通症例の報告はみ あたらない，僧帽弁穿孔の成因については，一般的に は感染性心内膜炎の治瘦経過に括いて僧幌弁癉を形成 し，それが破裂するといった場合が多いとされる(3)が

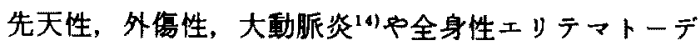
ス ${ }^{15)} と ゙ の$ 翏原病によるものなどす報告されている。 本症例では発熱など感染性心内膜炎を示唆する病歴,

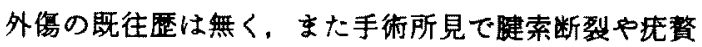
などは認めず弁穿孔部にも弁動脈瘤を形成した痕跡は 認めず，弁葉が菲薄かつ脆弱であったことから特発性 の穿孔と考えられた。

$$
\text { 結語 }
$$

ASDIに対するパッチ閉鎖手術から9年後にMR およびTRを伴 5 ASD 再開通の診断で再手術を施行 し，良好な結果を得た症例につき考察を加え報告した。

$$
\text { 文献 }
$$

1) Sellers RD, Ferlic RM, Sterns LP: Secundum type atrial septal defect : Early and late results of surgical repair using extracoproeal circula. tion in 275 patients. Surgery $59: 155-164,1966$

2) Amfred $E$ : The surgical treatment of atrial septal defect: One hundred cases operated with the aid of extracorporeal circulation J Cardiovasc Surg 7: 458-484, 1966

3) Cohn LH, Morrow AG, Braunwald E: Operative treatment of atrial septal defect : Clinical and hemodynamic assesments in 175 patients. Br Heart J 29 : 725-734, 1967

4) 林久恵, 小林尚子。遠藤真弘地：心瞊中隔欠損， 外科診療 $29: 805-811,1969$

5) Dave LS, Pakrashi BC, Wooler GH et al: Atrial septal defect in adults. Clinical and hemodynamic results of surgery. Am J Cardiol $31: 7-13,1973$

6) Young D: Later results of closure of secun- dum atrial septal defect in children. Am J Cardiol $31:$ 14-22, 1973

7) Breyer RH, Monson DO, Ruggie NT et al: Atrial septal defect: Repair in patients over thirty-five years of age. J Cardiovasc Surg 20: 583-586, 1979

8) Mizuno A, Fuse K, Furuta N: Long-term results following surgical closure of secundum atrial septal defect. Jpn Circ J 44: 904-910, 1980

9) Valdes-Cruz LM, Pieroni DR, jones $M$ et al: Residual shunting in the early postoperative period after closure of atrial septal defect. Echocardiographic comparison of patch mate. rials. J Thorac Cardiovasc Surg 84: 73-76, 1982

10) Körfer R, Bircks W, Frilling $A$ et al: Zweiteingriffe nach korrektur partieller endokardkissendefekte (Indikation, Haufigkeit, Ergebnisse). Zeitschrift für Kardiologie 73: 269 $-272,1984$

11) Ben-Zvi J, Hilder FJ, Samet P: Development of mitral insufficiency folklowing closure of ostium secundum atrial-septal defect. Am Heart J 91 : 83-86, 1976

12）猪股昭夫, 栗林良正, 不破野諴一他：二次孔心房中 隔再開通に僧帽并閉鎖不全症の進展括よび三尖閉 鎖不全症を合併した 2 再手術例，臨胸外 $3: 425$ $-431,1982$

13）豊增弘幸，青柳成明，赤須 蔽他：僧帽并動脈瘤の 臨床経験，呼吸之诰理 $29: 221-225 ， 1981$

14）梁瀬真之，若木邦彦，小泉富美朝他：僧帽并動脈留 を伴った大動脈炎症候群の1剖検例，心缄 10 ： 1263-1271, 1978

15）小池 龍、須磨久善，志熊 肃他：SLEを合併し 太修正大血管転位症の再手術治験例，日胸外会誌 $34: 1709-1714, \quad 1986$ 


\title{
RE-OPENING ASSOCIATED WITH MITRAL PERFORATION AFTER SURGICAL CLOSURE OF PRIMUM TYPE ATRIAL SEPTAL DEFFECT -A CASE REPORT-
}

\author{
Ryu KOIKE, Shinjiro SASAKI, Susumu SHIGUMA, Toshihiro KODAMA, \\ Hirotoshi MURAKI and Atsuro TAKEUCHI \\ Department of Thoracic Surgery, Osaka Medical College
}

A 40-year-old man who had undergone patch closure of a primum type atrial septal defect 9 years earlier was admitted to our hospital because of palpitation and dyspnea on exertion.

Further examination revealed a left-right shunt at the atrial level, mitral regurgitaiton of Sellers class III, and massive tricuspid regurgitation.

Re-operation was performed under standard cardiopulmonary bypass. An opening of $15 \times 15 \mathrm{~mm}$ in the initial patch closure was identified. Cuspal perforation of the anterior mitral leaflet was found, but there was no vegetation. The leaflet was very thin and fragile. The perforation was not recognized at the initial surgery. The tricuspid annulus was enlarged.

Mitral valve replacement using Duromedicus $29 \mathrm{M}$, tricuspid valve replacemant using Duromedicus $31 \mathrm{M}$, and closure of the re-opened atrial septal defect using an expanded polytetrafluoroethylene patch were performed.

The patient recovered completely from the surgery.

The incidence and pathophysiology of re-opening after the surgical closure of an atrial septal defect are discussed. 